\title{
SEQUENCING RE-DEFINES SPIRANTHES RELATIONSHIPS, WITH IMPLICATIONS FOR RARE AND ENDANGERED TAXA
}

\author{
Lucy A. DuecK ${ }^{1,3} \&$ KenNeth M. CAmeron ${ }^{2}$ \\ ${ }^{1}$ UGA/Savannah River Ecology Laboratory, Drawer E, Aiken, SC 29802 USA; \\ ${ }^{2}$ The New York Botanical Garden, Bronx, NY 10458-5126 USA \\ ${ }^{3}$ Author for correspondece: dueck@srel.edu
}

KEY WoRDS: conservation genetics, endangered species, polyploidy, sequencing, Spiranthes

\section{Introduction}

Species delimitation in the genus Spiranthes L.C. Richard (Spiranthinae, Cranichideae, Orchidoideae) has long been problematic, due mainly to morphological polymorphism confounded by hybridization and polyploidy, particularly in the $S$. cernua (L.) Rich. species complex (Correll 1950, Luer 1975, Sheviak 1982). Official records indicate that 462 taxa names have been used for Spiranthes historically (RBG-Kew 2006), but less than a tenth of those are recognized today, and there is still concern about the species status of some. Although Spiranthes is considered to have a worldwide distribution, only eight of these occur outside of temperate North America.

All 26 currently recognized Spiranthes taxa in the Flora of North America (Sheviak \& Brown 2002) have some form of conservation listing in a U.S. state (except $S$. casei var. novascotiae Catling, found only in Canada), due mainly to tenuous occurrence at the edge of their range in those locations. The less-serious listing denominations include: Exploitatively Vulnerable, Rare, Sensitive, and Special Concern. Two unrecognized taxa are other exceptions $-S$. amesiana (either extirpated or a synonym for $S$. torta [Thunb.] Garay \& H.R.Sweet) is Proposed Endangered by Florida due to endemicity and rarity, and newly described S. sylvatica P.M.Brown (Brown 2001a) has not been listed by any state.

Most of these Spiranthes taxa are also federally or state-listed as Threatened, Proposed Endangered, or Endangered (Table 1). However, some taxa, such as those endemic to or now limited to one or few locations, should be targeted for special protection. These include: S. brevilabris Lindl., S. delitescens Sheviak, S. eatonii Ames ex P.M.Br., S. floridana (Wherry) Cory, S. infernalis Sheviak, S. parksii Correll, and $S$. torta. Federally threatened $S$. diluvialis Sheviak is not endemic to one area, but rare throughout its range and unusual as an allopolyploid. Other taxa that can also be identified as genetically important as well as rare should be targeted for maintenance of biodiversity.

Molecular genetic techniques can provide a suite of markers from which to choose the scale of taxonomic discrimination required (Soltis \& Soltis 1998, Soltis \& Gitzendanner 1998, Avise 2004). Nucleotide sequencing, particularly of several genes in combination, is successfully used to address issues of phylogenetics and species delimitation, critical when conservation resources to protect threatened and endangered taxa must be focused. It is thus our goal in determining phylogenetic relationships among Spiranthes through sequence analysis to help identify these unique taxa and verify the taxonomic status of the endemic group members. Circumscribing the genetic individuality of these species of concern is a basic foundation on which to build further conservation efforts.

\section{Methods}

As part of a larger Spiranthes phylogeny project, all 27 taxa found in temperate North America have now been sampled except $S$. casei var. novascotiae and $S$. ovalis var. ovalis. Voucher specimens, when available, were deposited in the Clemson (SC) University herbarium (CLEMS). Three Spiranthes found in Europe and Asia (S. aestivalis [Poir.] Rich., S. sinensis [Pers.] Ames, S. spiralis [L.] Chevall.), as well as an outgroup taxon (Sacoila lanceolata var. lanceolata [Aubl.] Garay), were also included in the analyses.

DNA was extracted from the plant tissue, and four genes/regions representing all three genomes were sequenced according to protocols outlined in Dueck et al. (2005). The DNA segments analyzed include 
TABLE 1. Critical conservation listings for Spiranthes in the U.S.

\begin{tabular}{|c|c|c|c|c|c|c|}
\hline SPECIES & $\begin{array}{c}\text { Federal } \\
\text { Status }\end{array}$ & $\begin{array}{c}\text { GLOBAL } \\
\text { RANKING }\end{array}$ & $\begin{array}{l}\text { State } \\
\text { Status }\end{array}$ & $\begin{array}{c}\text { STATE } \\
\text { RANKING }\end{array}$ & STATE & NOTES \\
\hline S. brevilabris & & G1 & $\mathbf{E}$ & S1 & $\mathrm{FL}$ & 1 extant FL site \\
\hline S. casei v. casei & & G4 & $\mathbf{E}$ & S1 & $\mathrm{NH}, \mathrm{PA}$ & \\
\hline S. delitescens & $\mathbf{E}$ & G1 & HS & S1 & $\mathrm{AZ}$ & endemic to $1 \mathrm{AZ}$ site \\
\hline S. diluvialis & $\mathbf{T}$ & G2 & $\begin{array}{l}\mathbf{E} \\
\mathbf{T}\end{array}$ & $\begin{array}{c}\text { S1 } \\
\text { S2, S1 }\end{array}$ & $\begin{array}{c}\text { WA } \\
\text { MT, NE }\end{array}$ & found in 8 states \\
\hline S. eatonii & & & PE & & FL & 2 extant FL sites \\
\hline S. floridana & & G1 & PE & S1 & FL & 1 extant FL site \\
\hline S. infernalis & & G1 & $T$ & S1 & NV & endemic to $1 \mathrm{NV}$ site \\
\hline S. lacera & & & $\mathbf{T}$ & & IA & \\
\hline S. lacera v. gracilis & & G5 & $\mathrm{X} / \mathrm{PE}$ & & ME & \\
\hline S. laciniata & & G4G5 & $\begin{array}{c}\mathbf{E} \\
\mathbf{T} / \mathbf{E} \\
\mathbf{T}\end{array}$ & S1 & $\begin{array}{l}\mathrm{NJ} \\
\mathrm{NC} \\
\mathrm{FL} \\
\mathrm{SC}\end{array}$ & \\
\hline S. longilabris & & G3 & $\begin{array}{c}T \\
T / P E\end{array}$ & & $\begin{array}{l}\mathrm{NC} \\
\mathrm{FL}\end{array}$ & \\
\hline S. lucida & & G5 & $\begin{array}{c}\mathbf{E} \\
\mathbf{T} / \mathbf{E} \\
\mathbf{T}\end{array}$ & S1 & \begin{tabular}{|c|} 
IL, IA, MD \\
NC \\
KY, ME, NH, TN
\end{tabular} & \\
\hline S. magnicamporum & & G3G4 & $\begin{array}{l}\mathbf{E} \\
\mathbf{T}\end{array}$ & S1 & $\begin{array}{c}\text { GA, IN, NM } \\
\text { KY }\end{array}$ & \\
\hline S. ochroleuca & & G4G5 & $\begin{array}{c}\mathbf{E} \\
\mathbf{T} / \mathbf{E} \\
\mathbf{T} \\
\end{array}$ & S2 & $\begin{array}{c}\mathrm{MD}, \mathrm{TN} \\
\mathrm{NC} \\
\mathrm{IN}\end{array}$ & \\
\hline S. odorata & & G5 & $\begin{array}{c}\mathbf{X} / \mathbf{E} \\
\mathbf{E}\end{array}$ & & $\begin{array}{c}\mathrm{MD} \\
\mathrm{KY}, \mathrm{TN}\end{array}$ & \\
\hline S. ovalis v. eros. & & G5 & $\begin{array}{l}\mathbf{E} \\
\mathbf{T}\end{array}$ & S1 & $\begin{array}{c}\text { FL, PA } \\
\text { IA, MI, seUS }\end{array}$ & \\
\hline S. ovalis v. ovalis & & G5 & $\mathbf{E}$ & & FL & \\
\hline S. parksii & E & G3 & $\mathbf{E}$ & S3 & TX & endemic to east TX \\
\hline S. romanzoffiana & & G5 & $\begin{array}{l}\mathbf{E} \\
\mathbf{E} \\
\mathbf{T}\end{array}$ & S1 & $\begin{array}{c}\text { IN } \\
\text { MA, IL, PA } \\
\text { IA, OH }\end{array}$ & \\
\hline S. torta & & G4 & $\mathbf{E}$ & S1 & $\mathrm{FL}$ & endemic to south FL \\
\hline S. tuberosa & & & $\begin{array}{c}\mathbf{E} \\
\mathbf{T} / \mathbf{E} \\
\mathbf{T} \\
\end{array}$ & & $\begin{array}{l}\text { RI } \\
\mathrm{NJ} \\
\mathrm{FL}\end{array}$ & \\
\hline S. vernalis & & G5 & $\begin{array}{l}E \\
T\end{array}$ & & $\begin{array}{c}\text { IL, NH, NY, PA } \\
\text { MA, IA }\end{array}$ & \\
\hline
\end{tabular}

Main source: http://plants.usda.gov/threat.html

$\mathbf{X}=$ Extirpated/Historical

$\mathbf{E}=$ Endangered

$\mathbf{P E}=$ Proposed Endangered

$\mathbf{T}=$ Threatened

HS $=$ Highly Safeguarded
G1 = critically imperiled globally

G2 = imperiled globally due to rarity/vulnerability

G3 = very rare throughout range or found restricted locally

G4 = apparently secure globally but rare in some places

G5 $=$ demonstrably secure globally but rare in some places

$\mathbf{S 1}$ = critically imperiled in state; $\mathbf{S} \mathbf{2}=$ imperiled in state 
two plastid regions - a non-coding section of trnS-fM and the $\operatorname{trn} \mathrm{L}$ intron, one non-coding region in mitochondrial gene NAD7, and the nuclear ribosomal ITS region including ITS $1,5.8 \mathrm{~S}$, and 2 . Resulting electropherograms were contiged and edited, and the four matrices of consensus sequences were aligned. These data sets were then analyzed using the parsimony criterion in PAUP*, and support values for relationships were calculated by performing jackknife analyses of 5000 replicates. Since the separate gene trees were concordant, data were also combined and analyzed together, but only samples complete for all four genes were included.

Because the main project is still in progress, however, the four-gene cladogram shown here (from June 2006) does not include many samples subsequently collected. These later samples have been sequenced, but their analyses not rigorously tested yet, so their results will be discussed as preliminary findings only.

\section{Results}

Of the 123 total samples analyzed by June 2006, 99 samples were complete with all four gene sequences and thus were used to produce the figure included. Two taxa subsequently sampled ( $S$. porrifolia Lindl., S. torta) were not included in this analysis, but their placement is discussed below in light of more recent analyses. Other taxa not included due to unavailability are $S$. casei var. novascotiae, S. lacera var. lacera (Raf.) Raf., and S. ovalis var. ovalis Lindl. Over 3500 base pairs (bp) were used in the combined analysis, and statistically the ITS 1-2 segment had the most variable $(26 \%)$ and informative (18\%) sites. However, the $\operatorname{trn} S$-fM segment had the best-resolved topology for a single-gene tree (not shown).

A strict consensus cladogram of the Spiranthes phylogeny based on the four-gene combined analysis is shown in Figure 1, with jackknife support values added above branches. There is strong support (99\%) for a division of the genus into two major groups with some strong species clades within each. The lower group, a paraphyletic grade of taxa, contains distinct species S. infernalis and S. lucida (H.H.Eaton) Ames, and a weakly supported S. romanzoffiana Cham. clade in which strongly supported $S$. delitescens and unsupported but separate $S$. diluvialis reside. In single trees from maternally inherited plastid and mitochondrial genes, $S$. diluvialis was within the same clade as S. romanzoffiana, but in the tree based on nuclear ITS sequences, it was within the clade containing $S$. mag- nicamporum Sheviak (not shown). A moderately supported division (81\%) within the lower paraphyletic grade separates the latter five species from strong clades of combined S. praecox (Walter) S.Watson and S. sylvatica (no distinction between them shown from this analysis), all three Old World species, and $S$. tuberosa Raf. The upper group contains a moderately supported clade of closely related species, with $S$. brevilabris and $S$. floridana as distinct, but with $S$. eatonii and $S$. lacera as indistinguishable from each other. S. vernalis Engelm. \& A.Gray, S. laciniata (Small) Ames, and S. longilabris Lindl. are monophyletic and thus strongly supported species. S. ovalis var. erostellata appears as a strongly supported subclade within a broad unsupported $S$. magnicamporum-S. odorata (Nutt.) Lindl. group. S. odorata is polyphyletic, appearing within no fewer than three different clades. The two remaining derived clades consist of moderately strong support $(86 \%)$ for a $S$. cernua-S. parksii clade in which S. parksii is indistinguishable, and an unsupported clade with $S$. casei Catling \& Cruise and S. ochroleuca (Rydb.) Rydb. separate but also unsupported. No distinct identity for $S$. cernua was supported from these samples and analysis.

Preliminary results from "work-in-progress" analyses (not shown) indicate some important findings for species of interest to conservation biologists. Differentiation of $S$. eatonii from $S$. lacera was not resolved by additional $S$. lacera samples. S. porrifolia is very closely related to $S$. infernalis and in fact may be hybridizing in the southwestern limits of its range, but the clade containing both species are distinct from and sister to $S$. romanzoffiana. Our samples of $S$. torta are sister to $S$. laciniata (and both to S. brevilabris) in the maternal genomes, but to $S$. floridana when the nuclear genome is included. And although inclusion of more samples of $S$. cernua is providing a better species identity for it along a northeastern Appalachian swath, S. parksii remains imbedded within the clade of southern $S$. cernua.

\section{Discussion}

For the first time, our phylogeny of Spiranthes, based on molecular data from all three genomes, is revealing the relationships among taxa found in the United States and abroad. Whereas several other aspects of the study are interesting, our goal here is to focus on known target species (endemic/endangered) and define any new species (unique/rare) of conservation concern. 


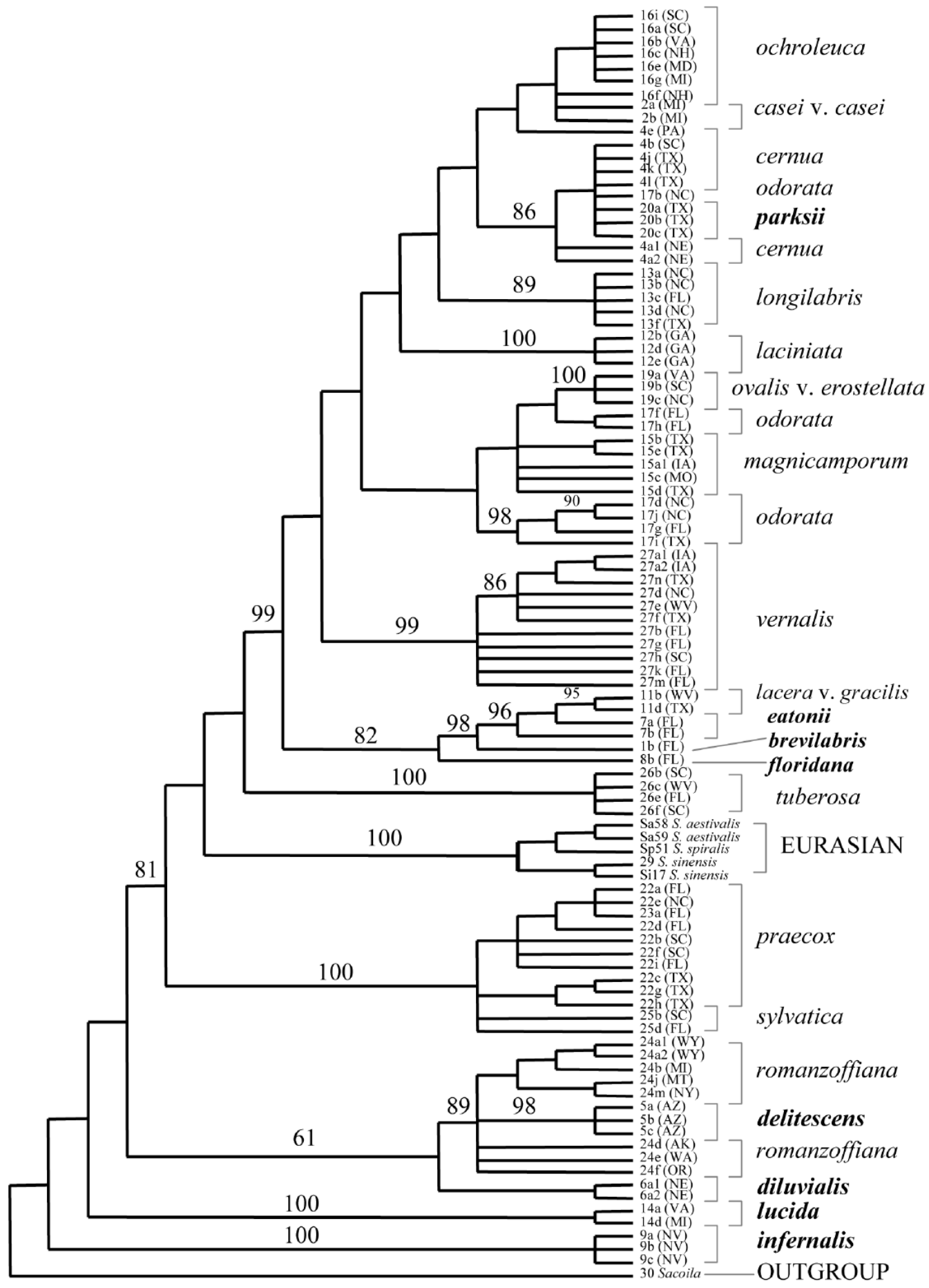

FIGURE 1. Strict consensus cladogram for taxa in Spiranthes genus, based on combined analysis of four genes/regions, from 489 trees (June 2006); jackknife support values $>80$ shown above branches; target species for conservation in bold. Two species subsequently sampled and analyzed but not included here are $\boldsymbol{S}$. porrifolia and $\boldsymbol{S}$. torta, both also of conservation concern. Sample identification numbers and U.S. state of collection shown at branch tips. 
Most importantly, federally listed $S$. parksii, endangered and endemic to east-central Texas, may simply be an aberrant form of the more widespread $S$. cernua, contrary to accepted taxonomy. Cladograms from more than 3500 characters show that individuals of southern $S$. cernua form a monophyletic clade that includes $S$. parksii within it. Thus, based on our data and the phylogenetic species concept, $S$. parksii may not warrant species status, and its protection may be questioned. The tetraploid chromosome number $(2 \mathrm{n}=60)$ of $S$. parksii and inclusion firmly within the S. cernua complex (Sheviak \& Brown 2002) suggests that polyploidy may play a role in its ambiguity.

In contrast, species status was supported by our data for the two other federally listed species, S. diluvialis (threatened) and especially $S$. delitescens (endangered), both members of a broad $S$. romanzoffiana clade. The previously documented allopolyploid origin of $S$. diluvialis was confirmed by these data, with $S$. magnicamporum verified as its paternal ancestor. Allopolyploidy has also been suggested for S. delitescens by Sheviak \& Brown (2002) based on the same chromosome number configuration $(2 n=74)$, but affinity with other than $S$. romanzoffiana was not confirmed by our data.

The genetic identity of all other state-listed Spiranthes species in the endemic/endangered group except one was confirmed. Although Wherry separated S. floridana from S. brevilabris in 1931 (as Ibidium floridanum, later changed to $S$. floridana by Cory and emended by Brown [2001b]), the epithet $S$. brevilabris var. floridana has persisted. Our study shows these rare taxa to be distinct species, each worthy of separate recovery plans. However, from the few samples of $S$. eatonii sequenced, we were not able to distinguish it genetically from $S$. lacera. Extremely rare $S$. torta does appear to be a distinct species but closely related to the above four taxa, although there is some evidence for its hybridization with $S$. laciniata, which could be confirmed by further studies.

Three taxa have also been identified as genetically isolated by our study. Extremely rare $S$. infernalis, also a member of the endemic/endangered group, is a distinct subclade within a broader $S$. porrifolia complex near the ancestral root of the topology. While $S$. porrifolia's range covers the West coast states, its occurrence is sporadic, so linkage with rarer $S$. infernalis enables more concern for its conservation, also. And $S$. lucida, listed by eight states, is perhaps the most unique taxon genetically as sister to all other
Spiranthes in our recent preliminary work, and thus worthy of concerted conservation effort. We therefore suggest consideration of $S$. infernalis and $S$. lucida for federal listing status based on their basal position in the Spiranthes phylogeny, genetic uniqueness within the genus, and rarity.

These data demonstrate that molecular technologies have the power to elucidate genetic identity, focusing funding eligibility and conservation efforts such as ex situ propagation on the most appropriate subjects for maintenance of biodiversity.

\section{ACKNOWLEDGEMENTS}

We are grateful for the assistance of: Travis Glenn, Cris Hagen, many volunteer collectors (especially R. Bischof, P. Brown, J. Foster, A. Hicks, C. Walters), U.S. Fish \& Wildlife Service, University of Idaho Herbarium, South Carolina Department of Natural Resources, and Royal Botanical Gardens - Kew. This research was supported mainly by the Environmental Remediation Sciences Division of the Office of Biological and Environmental Research, U.S. Department of Energy, through Financial Assistance Award \#DE-FC09-96-SR18546 to the University of Georgia Research Foundation, and partially by a research grant from the American Orchid Society for 2004-2005.

\section{Literature Cited}

Avise, J.C. 2004. Molecular Markers, Natural History, and Evolution. Second Edition. Sinauer Associates, Sunderland, MA.

Brown, P.M. 2001a. Recent taxonomic and distributional notes from Florida 11: Spiranthes sylvatica P.M. Brown, a new species of ladies'-tresses from the southeastern United States. North Amer. Native Orch. J. 7 : 193-201.

Brown, P.M. 2001b. Recent taxonomic and distributional notes from Florida 9. North Amer. Native Orch. J. 7(1) : 91-98.

Correll, D.S. 1950. Native Orchids of North America North of Mexico. Chronica Botanica Co.

Dueck, L.A, J.A. Fowler, C.S. Hagen \& T.C. Glenn. 2005. Genetic discrimination of Spiranthes cernua species complex in South Carolina. Selbyana $26(1,2)$ : 145-154.

Luer, C.A. 1975. The Native Orchids of the United States and Canada excluding Florida. New York Botanical Garden, NY.

Sheviak, C.J. 1982. Biosystematic study of the Spiranthes cernua complex. Bulletin \#448, New York State Museum. University of the State of New York, The State Education Department, Albany, NY. 
Sheviak, C.J \& P.M. Brown. 2002. Orchidaceae, Vol. 26, Spiranthes. Flora of North America. Published on the Internet at: http://www.efloras.org/florataxon. aspx?flora_id=1\&taxon_id=131021.

Soltis, P.S \& M.A. Gitzendanner. 1998. Molecular systematics and the conservation of rare species. Conserv. Biol. $13: 471-483$.

Soltis, D.E. \& P.S. Soltis. 1998. Choosing an approach and an appropriate gene for phylogenetic analysis. In D.E. Soltis, P.S. Soltis \& J.J. Doyle (eds.). Molecular
Systematics of Plants II: DNA Sequencing. Kluwer Academic Publishers, Norwell, MA, pp. 1-42 .

Walters, C. 2005. Genetic relationships among Spiranthes parksii and congeneric species. M.Sc. thesis, Texas A\&M University, College Station, Texas.

World Checklist of Selected Plant Families. 2006. The Board of Trustees of the Royal Botanic Gardens, Kew. Published on the Internet at: http://www.rbgkew. org.uk/wcsp/home.do, accessed 10/26/06.

Lucy Dueck, M.Sc., has been a Research Professional in molecular ecology at SREL, a field outpost for the University of Georgia, for over seven years. Her interest in Spiranthes phylogeny developed from producing a booklet on the wild orchids of South Carolina for outreach purposes. She obtained a grant from the AOS to pursue a thorough phylogenetic survey after completing a pilot study on selected Spiranthes in South Carolina.

Ken Cameron, Ph.D., is Director of the Lewis B. and Dorothy Cullman Program for Molecular Systematic Studies and an Associate Curator at The New York Botanical Garden. He has published extensively on the molecular systematics of various plant families, but maintains a primary research focus on orchids. In particular, he has applied DNA sequencing to questions of phylogeny for Vanilla and its relatives, as well as studies of Orchidaceae as a whole. 